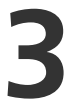

\title{
1958-1976: Three Rounds of Crises at the Initial Phase of Industrialization and the Background of Foreign Debts Due to Introducing Foreign Investment
}

After the Soviet Union withdrew its investment and technical support in the late 1950s, China's industrialization strategy could be summarized as follows:

1. Extracted surplus value from the agricultural sector through low purchasing price of agricultural products and high pricing of industrial products.

2. Forced the modernization of agriculture to absorb domestic industrial products through rural collectivization.

3. Mobilized intensive and massive labor input to substitute for capital under condition of extreme capital scarcity.

4. In case of economic crises, the transfer of unemployed labor force to rural sector through ideological mobilization. For example, intellectuals were sent to the countryside for "re-education" by the peasants and the youth were mobilized to build the rural sector. 
Unlike many developing countries, China had managed to build up a relatively complete industrial structure comprising of the primary, secondary and by then incomplete tertiary industries, which laid the foundation for development after 1978.

The year of 1978 is conventionally regarded as the point of departure of China's reform in spite of the fact that this was not the beginning of an economic cycle in that period. In reality, to understand the cyclicity of Chinese economy, a more appropriate approach is to delineate different periods in contemporary economic history by the years of outbreak of major crises. As per this principle, the first year of the Reform should be 1980 .

Since the Reform and Opening Up, many official experts and scholars have conducted in-depth studies on the economic volatility in China. Admittedly the reality of economic volatility is recognized by all researchers. Nevertheless, the existence of cyclical economic crises remains controversial. The author's essay in 1988 was the first study which clearly elaborated the problem of cyclical crises in Chinese economy. ${ }^{1}$ Before that, there was an unprinted manuscript circulating in Beijing's universities in 1979 with the title "Structural Economic Crisis in Socialism". It entailed striking ideological implication characteristic of the discussion during the late 1970s and early 1980s about whether economic cycles existed in socialist countries. This book tries to avoid this sort of ideological dispute. We identity and analyse the occurrence of crises from the functioning of the real economy. The discussion then covers the impact of crises on the rural sector under the dual structure of urban-rural dichotomy and the latter's role in mitigating against their detrimental consequences. The economic indicators quoted in this book include economic growth rate, fiscal deficits, the difference between financial stock and total loans, the growth rate in fixed asset investment, and CPI index etc. The reason for so doing is that there are two different

${ }^{1}$ Published in 经济学周报 (Economics Weekly Journal), 1988(5) and 新华文摘 (Xin Hua Digest), 1988(12). 
industrial stages of economic development that may be thought of as being divided by the reform.

Unlike advanced industrialized nations, late developing countries could not transfer the cost of primitive accumulation of capital outward through colonization or war. The only option has been the internal transfer of costs through specific social institutions. We call this the "theory of cost transfer".

It may be said that the social conflicts China experienced in the 1960s were the painful percussions of primitive accumulation of capital in the 1950s (two forms of capital: national capital and state capital). The costs were being transferred as the burdens of urban and rural citizens.

China's economic development, which has been mainly characterized by industrialization, can be divided into two different stages. Before the Reform, it was generally regarded as the initial stage of introverted industrialization, which can be known as the stage of primitive accumulation of capital according to classical theories. It is characterized by remarkable economic volatility, with clear features of economic cycle. During that period there were three major urban economic crises, approximately separated by $7-8$ years. The government's responses during these three crises had involved the transfer on a large scale surplus urban labour to highly organized people's communes and state-owned collective farms. In three rounds of "Going to Mountains and Villages" movements (1960, 1968, 1975) there was a total of about 20 millions urban youth (mainly high school students known as zhiqin, young intellectuals) and approximately an equivalent number of youngsters returning to their rural origins. Meanwhile, the government intensified the extraction of agricultural surplus, which can be regarded as an "inward" transfer of the cost of crises caused by industrialization and urbanization. In other words, not only did the sannong bear the institutional costs of primitive accumulation

\footnotetext{
${ }^{2}$ The studies of China often miss the dimension of the world. The World System in which China is situated is a system of transferring cost from advanced/core nations to less developed/peripheral nations. Accordingly, the greater the external pressure, the greater domestic tension would become. Or internal tension is a reflection of external pressure. This holds true between countries as well as between social sectors. For example, when the extraction of sannong's surplus becomes too much, social conflicts within rural community will also be intensified. Similarly, when the surplus of a country is being extracted too much by other, the tension between the state and the underprivileged groups will become exacerbated.
} 
for industrialization; it also acted as the major carrier bearing the costs of economic crises.

Compared with the crises since the 1980s after the Reform and Opening Up, these earlier crises differed in terms of the regions toward which the costs were transferred. During the 30 years before the Reform, state-owned industrial capital concentrated in cities could transfer the costs of crises to the rural sector through highly organized rural collectives. Urban economy and its governmental system could therefore be maintained intact.

In the three "young intellectuals going to countryside" movements during the 1960-1970s, 20 million unemployed urban youth were sent to the 4 million production teams of 800 thousand brigades in 90 thousand people's communes. Besides, there were about the same number of rural students returning to the 200 million rural households in the communes, which were not included in the government's statistics of employment (Image 1).

The correlation between cyclical urban crises and the "Going to Mountains and Villages" movements can be shown as below. On every occasion of crisis, the numbers of urban youth " zhiqin," literally young intellectuals) being mobilized to the rural regions would dramatically increase before decreasing again after the crisis passed. The political movement of Going to Mountain and Villages, isomorphic to the increasingly fortified urban-rural dual system, was the basic means by which the state transferred the costs of crises to the villages as large scale unemployment emerged in cities under crisis. The process continued until the completion of the primitive accumulation of capital for national industrialization (Fig. 1).

There has been little discussion about these social expenses or institutional costs of the primitive accumulation for state industrialization. The real unemployment rate was absent from official documents in that era. Comparing data in China Statistics Yearbooks, with urban employment number as 130 million in 1960 and 45.37 in 1962, the estimated unemployed labour might be around 85.36 million in the two years of recession. The number of urban employment was decreased by $65 \%$ (Fig. 2). 


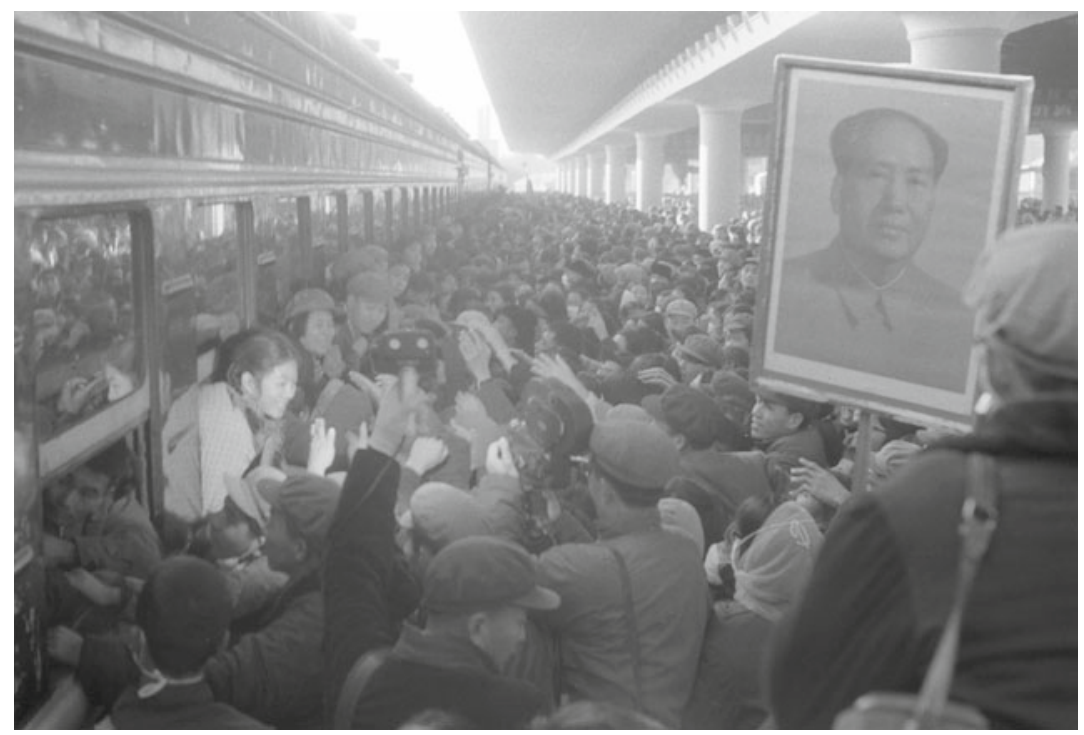

Image 1 In December 1967, 100 middle school students from Beijing were joining other thousands to volunteer to go to underdeveloped regions for the "Socialist Revolution and Construction". The picture shows the crowded Beijing Railway Station with the departing students and their parents

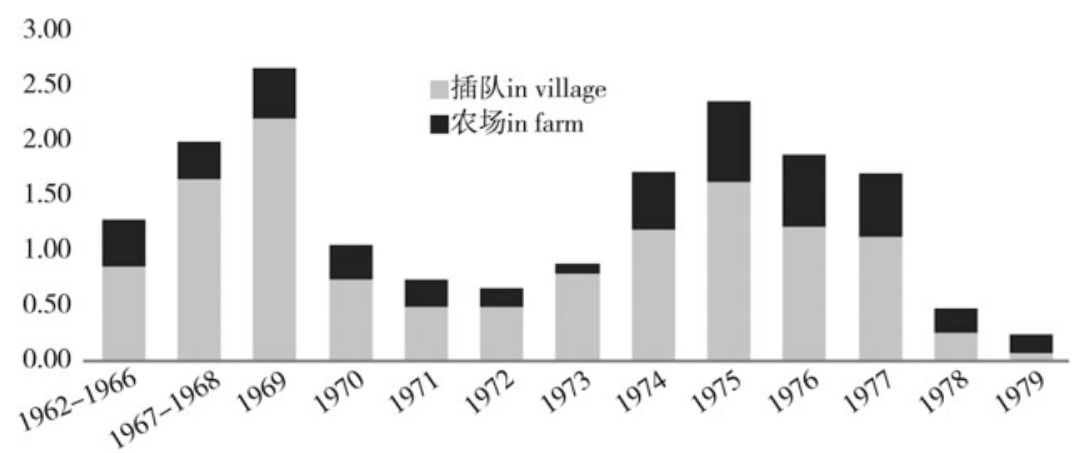

Fig. 1 Urban youth sent to rural regions during 1962-1979 (million) (Source: China Statistics of Labour and Wage) 


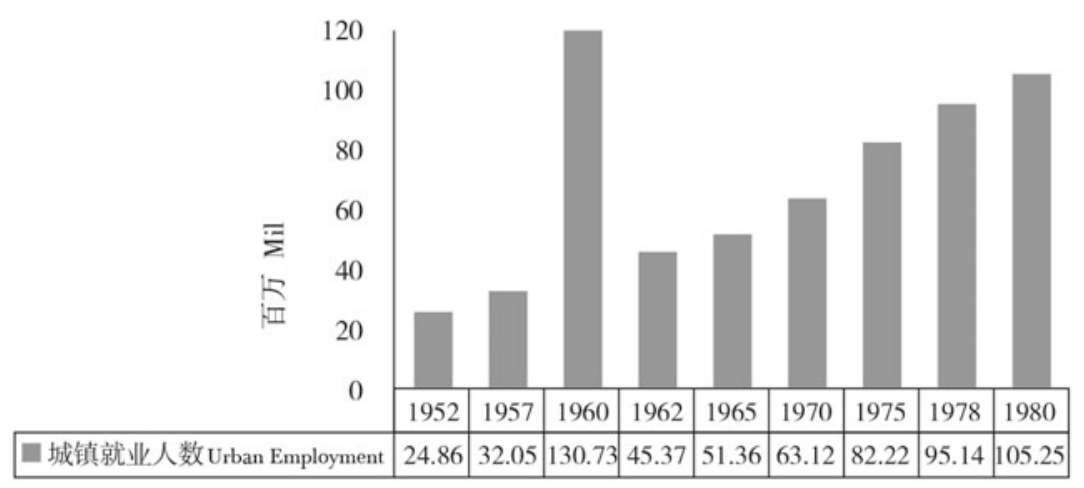

Fig. 2 Number of urban employed population (Source: China Statistical Yearbook 1996)

Under general market economy, an unemployment rate of more than $10 \%$ in any country would lead to serious social problems. There was no serious social unrest in China during that period. However, in the name of "class struggle" the problem was expressed in a variety of political movements as a way to mitigate social tension in the urban sector, where capital was concentrated along with accumulated risk. Furthermore, during these economic crises the state could have the potential unemployed urban labour almost totally absorbed by the rural sector through highly stabilized collectivized organizations (people's communes).

During the 2 July to 16 September 1959, the ruling party held several important meetings in Lushan, Jiangxi including the outreach session of the Politbureau and the Eighth Plenary Session of the Eighth Central Committee. In these meetings, the lessons since the "Great Leap" Movement of 1958 were summed up. However, the leaders and politicians at that time were still confined by the ideological opposition of Left and Right, which in fact originated from the West. These Lushan Meetings had left us with much astonishment and puzzles. However, few have understood that the complication incurred by the crisis of fiscal deficit was a necessary consequence of China's making use of foreign capital for the primitive accumulation of industrialization. China, the biggest sovereignty in the world, was offered the chance 
because it got embarrassingly involved into the geo-political strategies of two superpowers.

Unlike their previous suzerains, developing countries generally could not transfer the cost of primitive accumulation externally. All they could do was to transfer the cost internally under certain institutional conditions. It is a regular pattern. Late industrializing countries are no exception.

The painful difficulties and social contradictions China suffered during the 1960s can be attributed to the transfer of cost incurred by the primitive accumulation of industrial capital that occurred under different names (national capital or state capital).

\section{Background of the First Occasion of Industrialization Relying on Foreign Capital: The Reconstruction and Transformation of Geo-Political Strategy After WWII}

In the previous chapter, we have discussed the experience of socialist China in dealing with chronic hyperinflation.

This serious economic crisis of hyperinflation and unemployment occurred mainly in the cities. Rural China was relatively stable at that time and benefited from an all-round agrarian reform which represented the fundamental appeal of peasants in China for a few thousand years. In the name of Land Revolution, the government distributed land to some 400 million peasants and property rights were defined by the natural boundaries of villages. This effectively "delinked" the sannong (peasants, rural communities and agriculture) from the urban economy, which was prone to risk. And in pioneering a rural institutional arrangement, this system of property rights created a "path dependence". Henceforth, all political redistribution of land would set the village boundary as the limit to which property rights in land would apply. 


\section{Industrialization and the Dilemma of Urban-Rural Dual Structure}

Consequently, the peasants who comprised $88 \%$ of the population remained loyal to the new regime under the leadership of the ruling party. This was in accordance with a historical regularity in ancient China where the dynasty practising an equitable distribution of arable land and tax exemption would earn the loyalty of peasants. But what this particular historical instance amounted to was an exercise of mass mobilization for the nation-building of new China via a land revolution. This marks a fundamental institutional difference between China and other developing countries that have not undergone a similar popular land revolution.

However, this episode deepened a fundamental contradiction between the rural and the urban. The national capitalist industry had to face high transaction costs in trading with highly dispersed peasants in extracting the agricultural surplus. Under the threat of high inflation, peasants would become risk-averse and exhibit "non-monetized" behaviorgenerally the peasants would stockpile staple crops and purchase fewer urban industrial products.

Whenever entering into industrialization, all economic systems have to deal with the problem of transaction costs, which is a direct "institutional cost", no matter what kind of ideology a country claims to hold on to. If the costs cannot be transferred to the rural sector, it would be transferred to the urban milieu where industrial and commercial capitals are concentrated, the result of which would be a deteriorating business environment. In the primitive accumulation of national capital during 1949-1953, most of the cities in China witnessed the problems of counterfeit, speculation, corruption and favoritism. The new government, which did not yet have a firm footing in the cities, took advantage of its revolutionary prestige to mobilize the masses to deal with these problems by way of political movements. At that time, a class-based politics led by the working class having self-consciousness of proletarian class had yet to be formed and different classes including petit bourgeois, the majority of urban citizens and enterprise staffs, could vent their discontent through 
these movements, which functioned as pressure relief valve preventing the accumulated internal pressure from leading to radical social actions.

These political movements have been much criticized by latter generations. Nevertheless, the greatest pity of these historical experiences has not been discussed: the institutional costs incurred by the primitive accumulation of national capital in urban economy could not be dispensed with simply by mass mobilization in cities, which was a problem not presaged by the politicians of that time. The persistence of these "costs" may be considered to be the reason for the incomplete process of urban industrialization in most of the developing countries, notwithstanding the considerable social and political turmoil they have gone through.

These political movements should be contextualized into the initial development of urban capital and the urban-rural relationship. However, we have to take a further step to expand our perspective onto the international environment. International factors have always been decisive in China's different stages of development.

\section{The Price of Soviet Union's Aid: The Socialist Restructuring of Economic Base and the "Sovietization" of Superstructure}

After the victory in 1949, the new government attempted to accomplish the primitive accumulation of capital for national industrialization through developing the private sector (industry as well as commerce) and promoting urban-rural exchange. The idea was the government would lead the new small property owners emerging from the revolution and the entrepreneurs of urban private industry and commerce to gradually complete the primitive accumulation of national capital and to move into industrialization dominated by urban industry and commerce. During 1947-1950, it was expressed in official discourse as "New Democracy as National Capitalism under the Leadership of the CPC". The results of relatively autonomous development of local economies during 1950-1953 also testified this.

However, from the perspective of international geo-politics, China, like many late developing countries, was under the shackle of extreme 
capital scarcity and subject to unpredictable external tensions. After the establishment of the new socialist regime, the Chinese government adopted an overt pro-Soviet foreign policy. However, the Soviet Union did not immediately provide aid China desperately needed and asked for.

In December 1949, Mao Zedong on his first diplomatic mission flew to meet Stalin to negotiate a new treaty and various issues concerning their countries' bilateral interests. However, the process was not smooth. It was not until 14 February 1950 that the two leaders signed a series of agreements. The Soviet Union would help China to build 50 projects in coal, electricity, steel, nonferrous metal, chemical industry, machinery and military industry, which marked the beginning of three rounds of partnerships totalling 156 aid projects (see Box 1).

Compared with the difficult negotiations, the execution of these projects was highly efficient, with the reason being the Korean War. Only superpowers were capable of remaking the geo-political setting, which marked the great difference between them and other developing countries, including China, at that time.

The outbreak of Korean War in 1950 substantially changed the imperialist geo-political structure formed after the WWII. In October 1950, the Chinese People's Voluntary Army crossed the Yalu River. During the 3 year war, 1.34 million of armed persons were mobilized to confront an allied force of 1.11 million, 540 thousand of which was American. Paying a high cost, with a sacrifice of 140 thousand lives and 250 thousand injured, captured and missing in action, China managed to forge a strategic alliance with the Soviet Union, laying the foundation for the aid between 1950 and 1959, which was worth about 5.4 billion US dollars (including the military expenditures during the war).

With the strong pull of external investment accompanying the Korean War, China rapidly got out of the economic slump after 1950 and began the process of rapid primitive accumulation for industrialization. Because of the war, military purchases increased. Military and civil sectors competed for material supplies. The prices of industrial goods such as hardware, construction materials and general merchandises rose. For example, the price increase of construction materials was up by $82.9 \%$. The prices of some industrial appliances even rocketed by ten times due to speculation. 


\section{Box 1: 1950-1953 Soviet Union's Aids to China's Economic Construction}

New China's economic restoration was almost synchronized with the Korean War. During the war, China and the Soviet Union not only coordinated in military and diplomatic fields but also consolidated economic cooperation.

According to the report of the State Statistics Bureau on 11 March 1953, China and the USSR had signed contracts with the former agreeing to import facilities worth 683,940 thousand ruble during 19501953. The real accumulated imports were worth 469,740 thousand ruble, i.e. the completion rate of contracts was $68.7 \%$.

Soviet aid focused on energy and fundamental industries. It was pivotal in China's modern industry infrastructure building during the 1950-1952 rehabilitation period.

\begin{tabular}{|c|c|c|c|c|c|}
\hline & \multirow{2}{*}{$\begin{array}{l}\text { Project } \\
\text { Number }\end{array}$} & \multirow[b]{2}{*}{$\begin{array}{l}\text { Reconstruction } \\
\text { \& Expansion }\end{array}$} & \multirow[b]{2}{*}{$\begin{array}{l}\text { New } \\
\text { Projects }\end{array}$} & \multicolumn{2}{|l|}{ Regions } \\
\hline & & & & Northeast & Hinterland \\
\hline \multicolumn{6}{|l|}{ 1. Energy } \\
\hline i. Coal & 10 & 5 & 5 & 8 & 2 \\
\hline ii. Electricity & 11 & 5 & 6 & 6 & 5 \\
\hline \multicolumn{6}{|l|}{$\begin{array}{l}\text { 2. Raw } \\
\text { Materials }\end{array}$} \\
\hline i. Steel & 3 & 2 & 1 & 3 & \\
\hline $\begin{array}{l}\text { ii. Non-ferrous } \\
\text { Metals }\end{array}$ & 3 & 1 & 2 & 3 & \\
\hline iii. Chemical & 5 & & 5 & 4 & 1 \\
\hline $\begin{array}{l}\text { 3. Civil } \\
\text { Machinery }\end{array}$ & 7 & 2 & 5 & 7 & \\
\hline $\begin{array}{l}\text { 4. Defence \& } \\
\text { Military }\end{array}$ & 7 & 7 & & 4 & 3 \\
\hline $\begin{array}{l}\text { 5. Paper } \\
\text { Manufacturing }\end{array}$ & 1 & & 1 & 1 & \\
\hline Total & 47 & 22 & 25 & 36 & 11 \\
\hline
\end{tabular}

During 1950-1952 China's new increased fixed capital amounted to RMB 5.9 billion. Increment of productivity in energy and raw materials were as follows: electricity: 222 thousand kilowatt, coal extraction: 15,637 thousand tons/year, pig iron 764 thousand tons/year, steel ingot 558 thousand tons/year, rolled steel 336 thousand tons/year. 


\begin{tabular}{|c|c|c|c|c|c|c|}
\hline \multirow[t]{2}{*}{ Projects } & \multicolumn{2}{|c|}{ Construction Production } & \multirow{2}{*}{$\begin{array}{l}\text { Investment } \\
\text { (RMB 10 } \\
\text { thou- } \\
\text { sand) }\end{array}$} & \multicolumn{3}{|c|}{ New Increased Productivity } \\
\hline & at & at & & Products & Unit & Amount \\
\hline \multicolumn{7}{|l|}{ 1. Coal } \\
\hline $\begin{array}{l}\text { Liaoyuan } \\
\text { Central }\end{array}$ & 1950 & 1955 & 5770 & $\begin{array}{l}\text { Coal } \\
\text { Extrac- }\end{array}$ & $\begin{array}{l}\text { thousand } \\
\text { tons }\end{array}$ & 900 \\
\hline Fuxin Pingan & 1952 & 1957 & 8334 & tion & & 1500 \\
\hline Fuxin Haizhou & 1950 & 1957 & 19,472 & & & 3000 \\
\hline $\begin{array}{l}\text { Hegang } \\
\text { Dongsan }\end{array}$ & 1950 & 1955 & 6512 & & & 900 \\
\hline $\begin{array}{l}\text { Hegang } \\
\text { Xingantai }\end{array}$ & 1950 & 1956 & 7178 & & & 1500 \\
\hline \multicolumn{7}{|l|}{ 2. Electricity } \\
\hline Fuxin Thermal & 1951 & 1958 & 7450 & Capacity & thousand & 150 \\
\hline Fushun & 1952 & 1957 & 8734 & & kilowatt & 150 \\
\hline $\begin{array}{l}\text { Fengman } \\
\text { Hydroelec- } \\
\text { tricity }\end{array}$ & 1951 & 1959 & 9634 & & & 422.5 \\
\hline $\begin{array}{l}\text { Hulan Ergi } \\
\text { Thermal }\end{array}$ & 1952 & 1955 & 6870 & & & 50 \\
\hline $\begin{array}{l}\text { Zhengzhou } \\
\text { Second } \\
\text { Thermal }\end{array}$ & 1952 & 1953 & 1971 & & & 12 \\
\hline Chongqing & 1952 & 1953 & 3561 & & & 24 \\
\hline Xian Thermal & 1952 & 1957 & 6449 & & & 48 \\
\hline $\begin{array}{l}\text { Urumqi } \\
\text { Thermal }\end{array}$ & 1952 & 1959 & 3275 & & & 19 \\
\hline \multicolumn{7}{|l|}{ 3. Steel } \\
\hline \multirow[t]{3}{*}{ Anshan Steel } & 1952 & 1960 & 268,500 & Pig iron & thousand & 2500 \\
\hline & & & & Steel & tons & 3200 \\
\hline & & & & $\begin{array}{l}\text { Rolled } \\
\text { Steel }\end{array}$ & & 2500 \\
\hline \multicolumn{7}{|l|}{$\begin{array}{l}\text { 4. Nonferrous } \\
\text { Metals }\end{array}$} \\
\hline \multirow[t]{2}{*}{$\begin{array}{l}\text { Fushun } \\
\text { Aluminium }\end{array}$} & 1952 & 1957 & 15,619 & $\begin{array}{l}\text { Aluminium } \\
\text { ingot }\end{array}$ & $\begin{array}{l}\text { thousand } \\
\text { tons }\end{array}$ & 39 \\
\hline & & & & Magnesium & & 1.2 \\
\hline $\begin{array}{l}\text { Harbin } \\
\text { Aluminium } \\
\text { (Phrase I \& II) }\end{array}$ & 1952 & 1958 & 32,681 & $\begin{array}{l}\text { Rolled } \\
\text { Aluminium }\end{array}$ & & 30 \\
\hline $\begin{array}{l}\text { Shenyang } \\
\text { Pneumatic }\end{array}$ & 1952 & 1954 & 1893 & $\begin{array}{l}\text { Pneumatic } \\
\text { tools }\end{array}$ & $\begin{array}{l}\text { thousand/ } \\
\text { ton }\end{array}$ & $20 / 554$ \\
\hline
\end{tabular}

According to the table below, after the total completion of all aid projects, the new increased fixed assets were worth RMB 4.139 billion. The new increased productivity was as follows: electricity 875.5 thousand kilowatt, coal extraction 7800 thousand tons/year, pig iron 2500 thousand tons/year, steel ingot 3200 tons/year, rolled steel 2500 thousand tons/year. 
The second batch of the 156 projects was executed along with the First Five Year Plan.

During August-September, 1952, Premier Zhou Enlai led a delegation to negotiate with the USSR government. The agreement involved the latter helping China to build and reconstruct 91 enterprises. Including the 50 projects already under construction, the 141 projects would greatly enhance China's industrial capacity by 1959. Production capacity would be doubled in ferrous metallurgy, nonferrous metals, coal, electricity, petroleum, machinery manufacturing and chemical industry. China would have an automobile and a tractor industry. Productivity of major products such as steel, coal, electricity and petroleum would be equivalent to that of the USSR in the First Five Year Plan, and close to or even surpassing Japan in 1937 (the year when Japan launched overall war against China).

The import of complete-set facilities from the USSR related with the First Five Year Plan was conducted in the form of trade. In return, China had to supply 160 thousand tons of tungsten concentrate, 110 thousand tons of tin, 30 thousand tons of stibium, 35 thousand tons of molybedenum, 90 thousand tons of rubber and a certain amount of agricultural products. In comparison, the major aid projects during 1950-1952 were provided through loans. As for necessary scientific and technological information, the USSR provided in two ways: library information exchange and contracts. During the period of strategic partnership, China enjoyed special favour. The cost was low and at times, even free. However, the remuneration of experts working in China became a matter of negotiation.

Relying on foreign facilities to push national industrialization, China faced the problem of "human capital" scarcity. For example, in the 1950s, merely a few of the cadres in Northeast region were educated. 70\% of them were illiterate and semi-illiterate. Some received basic literacy training after taking part in the revolution. Scientists, technicians and administrative talents indispensable for industrialization were in extreme scarcity. Therefore, tens of thousands of USSR experts came to China along with the introduction of technology and facilities.

However, the negotiation concerning how they would be remunerated was not easy. When Liu Shaoqi visited the USSR, Stalin suggested that China could pay the USSR experts according to the remuneration 
level of top Chinese counterparts. The Soviet Union would subsidize the difference. Nevertheless, things became different afterward, especially after China insisted on maintaining its sovereignty on issues such as the Chinese Changchun railway, etc.

The Soviet Union proposed double payment, i.e. apart from paying the salary, Chinese government had to compensate 2000-4000 rubble for each expert to the enterprises or departments he or she worked in, payable to the USSR government. The US dollar value of this was equivalent to $10,000-18,000$ jin of millets. At that time, the salary of chairman and vice-chairman in China was merely 3400 jin of millets, ministers only 2800 . The Chinese government wished to pay by various staple foods and commodities, which was much easier than paying in US dollar, but the USSR insisted on payment by foreign exchange (in rubble according to US dollar exchange rate). It was finally agreed that Soviet experts be paid at the level of their top Chinese counterparts. In addition, China had to pay compensation for their absence from the Soviet economy, by 1500-3000 rubble per month. Moreover, the issue of remuneration and compensation of soviet military personnel in China also went through various negotiations.

Source: 沈志华 (Shen Zhihua), “新中国建立初期苏联对华经济援 助的基本情况一一来自中国和俄国的档案材料” (Basic Situations of USSR Aid to China-from the archives of China and Russia). Russia Studies, 2001(1-2).

China's industrialization was in fact dominated by foreign strategic investment made possible by the geo-political strategic competition between two super powers, the United States and the USSR.

The key projects during 1950-1952 were introduced as loans, totalling USD 300 million in value, to be repaid in 10 years, with annual interest rate of $1 \%$. Later after the loan agreement, the Soviet Union requested precious strategic materials such as tungsten, tin and stibium to repay the loan. Despite the additional terms, the loan condition was generally favourable. However, on the second batch of aid projects, the Soviet Union requested to be conducted more in the form of trade, especially in those projects related with importing whole sets of equipment. 
For example, China was requested to supply to the USSR 160 thousand tons of tungsten ores, 110 thousand tons of tin, and 30 thousand tons of stibium, 35 thousand tons of molybdenum ores and a substantial amount of agricultural products before 1959 .

This put great pressure on China. As the central government was the agent of accepting these aid projects, it was also responsible for the financial liability. Right at the beginning, China had to face the dilemma of foreign investment bearing foreign debts, or no investment at all. The pressure on the central government was double. On the one hand, it had to provide accessories for the imported equipment and facilities. On the other, the government's fiscal budget had to be spared to purchase products for exchanging. At that time, the problem could not be resolved by increasing money supply, otherwise the hyperinflation that was just being tamed (see previous chapter) would be set loose again. Furthermore, with heavy industry requiring big investments, facing high-risk and a long returns cycle, it was impossible to be financially self-sufficient. Under this extreme scarcity of capital, how to resolve the problem?

\section{Institutional Transition and New Ideology}

The only option available seemed to be the Unified Purchase and Selling system, which was put into pilot experiment in 1951 and became wellknown in 1952 as it was expanded to staple grain purchase. Only by unifying purchases in the rural sector and selling in the urban sector could price and supply become controllable. The central government's supplies and cash flow would not be broken. Therefore we suggest that the socialist transformation since 1953 was in fact an expanded version of the unified purchase and selling system China had explored.

Due to the problem of transaction cost, a full-scale unified purchase and selling system must be supplemented by new organizational innovation, the core of which was to reinforce cooperation to lead individual economic agents. It was embodied in three major aspects of socialist transformation: peasant households, urban artisan workers and capitalist industry as well as commerce. 
It was called "socialist" transformation, the "general line of socialist transition".

Now, under full-scale orientation toward the USSR, China rapidly formed a Stalinist system to accommodate heavy and military industries imported from the former. A state capitalist industrial system took shape and was mainly located in large and medium cities. Then, according to the requirements in terms of investment, construction and repayment supporting state capital, the general line of socialist transition was pushed through. By the end of January 1956, all capitalist industry and commerce in large cities and more than 50 medium cities had become joint state-private ventures. Before long, the socialist transformation of industry and commerce, as well as peasant economy was completed.

Taking advantage of the centralized system led by a single party formed during the revolutionary war, three major factors of production were converted into state ownership under state capitalism: land, labour and capital.

1. Land-In February 1954, the central government promulgated the following: "state-owned enterprises, state institutions, army and schools can expropriate sub-urban land without paying fee or rent." This implied that land ownership which would have generated high yield by urban and industrial sectors was assumed by the government, which was then able to appropriate the added-value from the capitalization of land. (In 1956, rural land ownership was transferred to village collectives.) This condition may be called "government corporatism". The problem then became obvious. Expropriation without compensation had driven the first wave of land enclosure during the mid-1950s. According to a report in 1956, among 101 thousand $m u$ of land expropriated in regions such as Beijing, Wuhan, Changsha, Hangzhou, Chengdu, etc., 41 thousand, around $40 \%$ was desolated or wasted. The situation was similar to the three rounds of land enclosure after the Reform since 1978.

2. Labour force-Since 1953, the government closed urban and rural labour markets to concentrate labour and intellectual resources into infrastructure building. All the surplus value of the labour force was appropriated by the government. In the three decades before the 
Reform, urban citizens enjoyed social benefits from the cradle to the grave, which were subsidized by the state. On the one hand, the state extracted almost all of the surplus value of urban labour with "the promise of the future" and laid the foundation of the high-speed accomplishment of primitive accumulation of capital for national industrialization. On the other hand, peasants, comprising $80 \%$ of the population, who enjoyed little from the benefits of industrialization, contributed greatly to converting urban citizens, who were mainly staff working in state-owned enterprises, into a "middle-class" as a social force stabilizing society.

3. Capital-The government monopolized money supply and controlled the whole financial sector, appropriating seignorage and the added-value of monetization of economy.

The private ownership of the factors of production had existed only for less than seven years in New China before they were converted into state ownership to serve the primitive accumulation of national industrialization. Capital therefore became embedded in the government. This government corporatism with Chinese characteristics, under the condition of capital scarcity, proved to be effective in accelerating primitive accumulation for industrialization. It was an institution beneficial to the rapid expansion of industrial capital in cities. Nevertheless, it was also an institution which directly transferred the institutional costs of crises onto the peasants.

New Democracy (National Capitalism) existed only till 1953. Thereafter, the state as the recipient of foreign industrial investment, rapidly transformed national capitalism into state capitalism. ${ }^{3}$ Within western ideological understandings, it was a "centralized system". This institution was set up upon the completion of socialist transformation in 1956 and continued until 1960 when a debt and deficit crisis broke out. Its essence was to introduce technologies and facilities from the USSR in the form of national debts. The central government then extracted surplus from

\footnotetext{
${ }^{3}$ National capitalism (New Democracy) meant developing capitalism with private capital as economic agents under the leadership of the state. State capitalism meant the state became the sole owner and agent of capital.
} 
the sannong based on large-scale collectivization with village and town as units, repaying debts and accomplishing industrialization.

In order to implement an institutional transition, the ruling party had to construct a logical explanation with moral legitimacy, in turn turning it into an ideology to lessen the cost of institutional transition. It was reflected in the debate between Mao Zedong and the Confucian intellectual Liang Shuming. Here, socialism represented the public interest. Mao considered himself representing national interest in long run whereas Liang represented individualist kindness. In that particular era, Mao, when confronted by a more inclusive and native Confucian discourse, opted for a more radical western revolutionary discourse to construct his value logic.

During the First Five Year Plan, the USSR provided strategic aid and investment to China while the latter set up governments, schools, and research institutions complying with the Soviet management model. The superstructure had to be brought into conformity with the economic base. In order to comply with the industrial economic base formed by the Soviet investment, China's superstructure, including its ideology, was totally "sovietized" in that period. Russian experts coming to China not only worked as managers in factories and enterprises but also helped to overhaul the entire superstructure of China. The eight major industrial departments, the Planning Committee, Financial Committee, Economic Committee, Agricultural Committee, etc., were all set up according to Soviet model. The officials sent from the USSR were called "experts". They were everywhere in every department. Chinese governmental and university systems were copied from the Soviet Union. Only in this way could the governmental institutions adapt with the management of Soviet industrial economy. During the first half of the 1950s, the urban economy was managed by a Soviet system.

Nevertheless, the Chinese leadership, which had a long experience in anti-colonial and anti-imperialist struggle, was alert to the problem of complete "sovietisation" of the superstructure (including the army). Before the 20th Party Congress of the Communist Party of the Soviet Union (CPSU) in 1955, the Communist Party of China had already held internal discussion about the problems of complete sovietisation, which foreshadowed the breakup of the two parties. 
The problem of complete sovietisation during the early 1950s became ingrained in Chinese government. Hierarchical soviet system fostered bureaucratism, dogmatism and formalism, which merged with the factionalism shaped during the guerrilla war. Not even massive popular mobilization in the Great Cultural Revolution could succeed in overthrowing this factionalism, to say nothing about the more gentle reforms subsequently.

The industrial economy led by state capital in cities stood in opposition to the traditional peasant economy rehabilitated in rural China after agrarian reform. Upon it thus rested an urban-rural dual system. The "path dependence" of this structure in the subsequent institutional transform in the next 50 years has been remarkable. Factionalism has become a pertinacious illness in contemporary China where politics is under the sway of interest blocs.

In summary, the Korean War afforded new China with the opportunity to introduce foreign investment for the first time. Transplanting Soviet production facilities along with its superstructure, China built an infrastructure of military-heavy industry and social institutions according to the Soviet model in order to accommodate the latter's mode of production. However, the price of fast industrialization was high. It was impossible to sell the obsolete industrial products overseas to cover the cost of industrialization in the cities. The foreign debt thus incurred had to be repaid by exporting produce and minerals not relatively abundant in supply in China while a domestic market had to be created to absorb these industrial products. For this reason, the state had to extract agricultural surplus from the agrarian sector through large-scale collectivization at village and township levels. Without taking these factors into consideration, it would be hard to depict a more objective picture of the turbulent 1960s of China unless we are content with those ideological perspectives prevalent in many researches. 


\section{The Second Crisis (1958-1960): What Happened in China After the USSR Aid was Interrupted?}

The economic crisis of 1958-1960 was the first cyclical crisis since China began receiving foreign investment to initiate and spur its industrialization. The trigger was China's insistence on its territorial integrity and independent sovereignty. According to the agreement of 1956, the USSR had to return the Chinese Changchun railway and the Dalian Special Zone to China and retreat its military base in Northeast China. Dissatisfied with this, the USSR interrupted aid and investment in 1957. In 1958, it requested to forge a new military alliance by establishing a joint navel-air force command and unified radio communication system in China to better serve the former's military strategy in the Far East. Mao refused and responded in his characteristic fashion: "You may take China. I would go back to Jinggang Mountain [to fight a resistance war]."

For Chinese leaders, national sovereignty was not negotiable. However, without foreign aid, the heavy-industry-oriented government corporatism relying on external investment became unsustainable. The Second Five Year Plan, which was coordinated under the assistance of Russian experts, was also aborted.

Modern history has consistently demonstrated that if a developing country insisted on its sovereign integrity and refused too much concession in its national interest, foreign investment and aid would be interrupted. Many often, its economic reproduction and development would be disrupted, causing the collapse of its economic base. As a consequence, the corresponding superstructure (government, political system, etc.) modeled after the template of the advanced country would become unsustainable without the support of continuing investment. In many cases, this situation would result invariably in political turmoil.

In response, China's central government managed to secure followup investment on a few dozen projects as a way to maintain minimum diplomatic relationship with the USSR. Additionally, it had to adhere to 
certain unanticipated measures and make necessary institutional adjustments (not to be known as "reform" at that time). In 1958, the central government proposed to mobilize local governments into national industrial construction formerly monopolized by the central government. The mobilization of domestic and especially local public fund was barely able to support the national economy oriented mainly toward heavy industry. In 1958, the weight of local fiscal expenditures in national fiscal budget jumped from $29.0 \%$ (1957) to $55.7 \%$ (Fig. 3).

During 1957-1958 when there was a significant decrease of investment from the USSR, the central government decentralized the power of fiscal budget, planning and enterprise management. Local governments were mobilized to build "five small-scale industries". ${ }^{4}$ However, the local governments which were granted such power for the first time had no time to learn how to proceed with industrialization. The only model they could imitate was the heavy-industry model the central government received from the USSR. As a result the fanatic industrialization initiative of local governments would eventuate in ridiculous practices such as the "Great Steel Forging" and the "Great Leap Forward".

Meanwhile, the central government, whose weight in total fiscal revenues dropped to $20 \%$ in 1958 , accelerated the pace of accumulation by increasing money supply. Even though the shortage of agricultural products led to price fluctuations in small local markets, the official general price changed little due to the limited purchasing power of money notes under the voucher system. Furthermore, because of the control of unified purchase and selling, the quantity of commodities available for trade in the market was limited. Therefore, the increased money supply could be withdrawn from circulation into bank deposits to build funds to support accumulation and reproduction for the national economy. At the same time, budget deficits rose remarkably. Although the growth rate of fiscal revenues and investment decreased, their absolute values stayed at a high level during 1958-1960, until the full crisis of fiscal deficit broke out in 1960 .

4胡鞍钢 (Hu Angang) 中国政治经济史论 (On China’s Political Economic History). Tsinghua University Press, 2008: 247-251. 


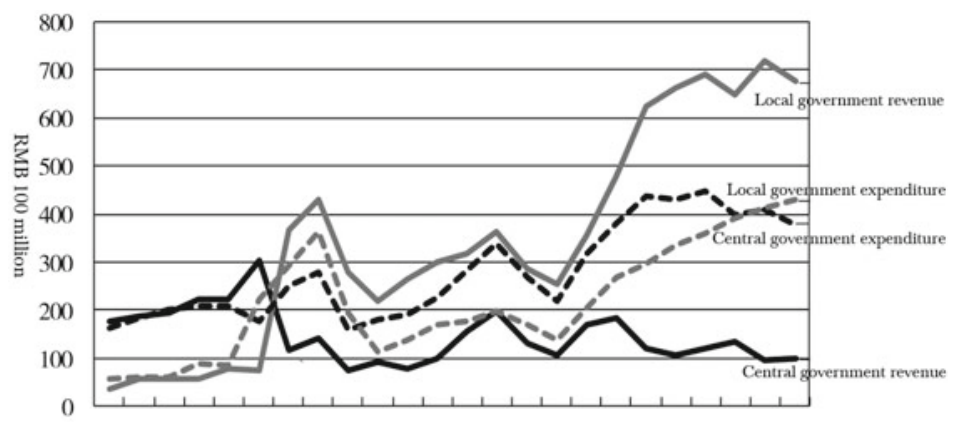

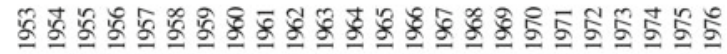

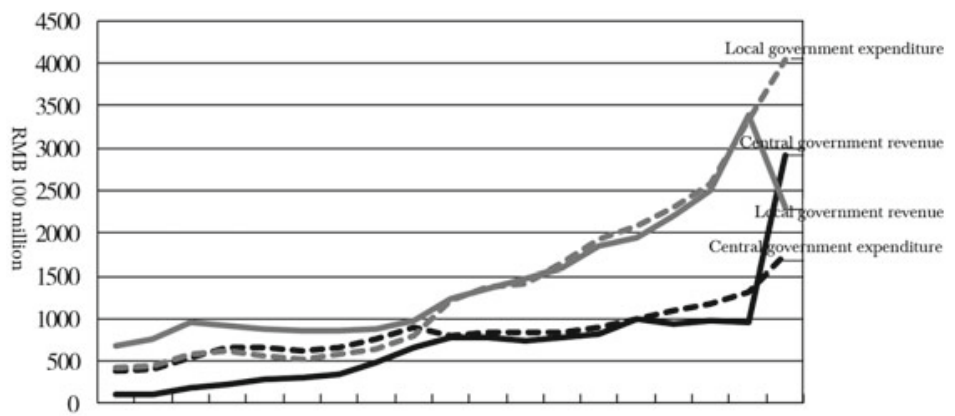

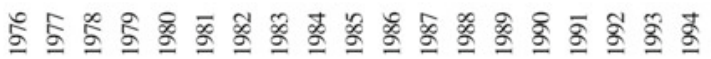

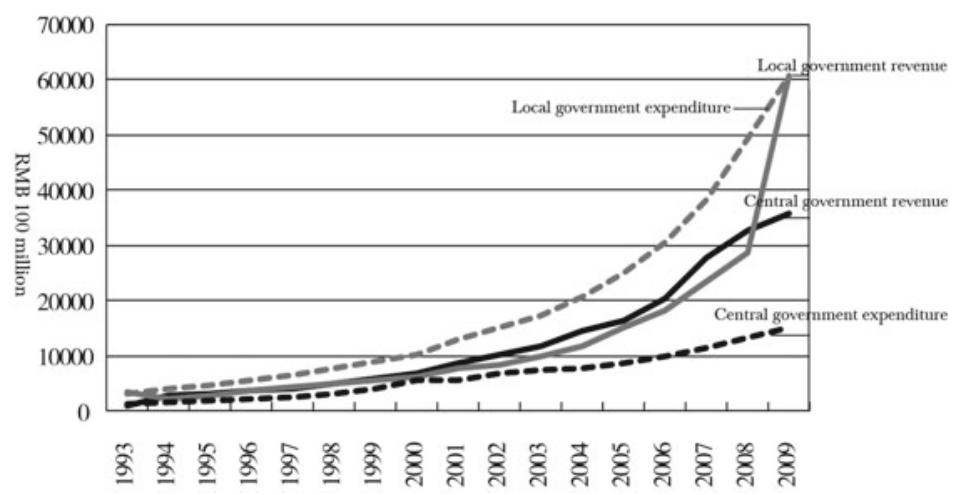

Fig. 3 Fiscal revenues of central and local governments 1953-2009 (Remark: since 1994, fiscal revenues no longer included domestic and foreign loan. Loan repayment and related costs were also excluded from fiscal expenditures. After 2000 , loan repayment was once again included) 


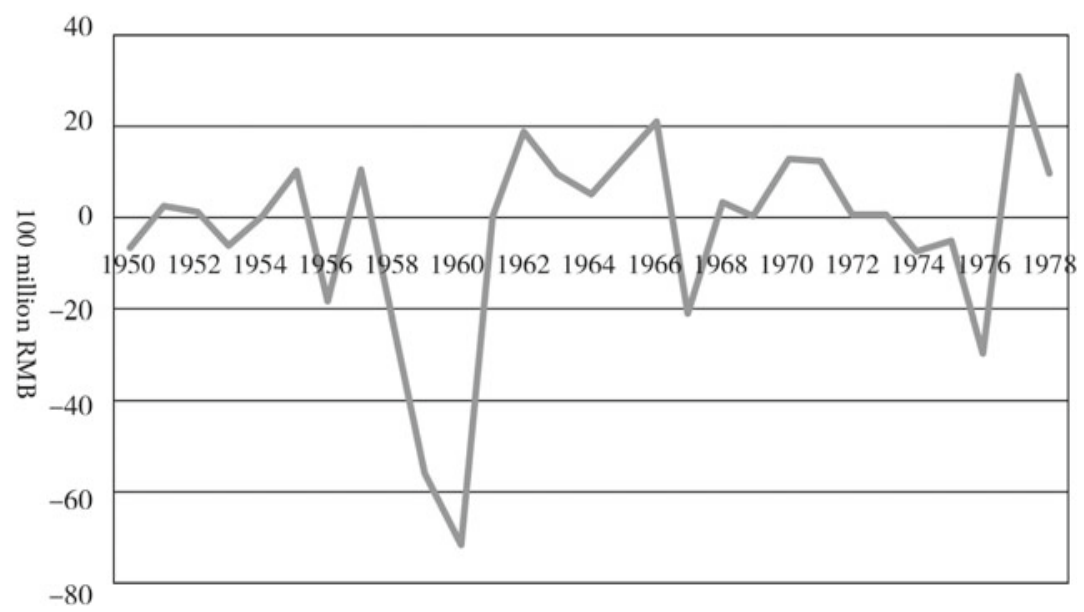

Fig. 4 China's fiscal balance before 1978 (Excluding Debt Balancing)

Figure 4 shows three stages. During 1953-1976, central and local annual fiscal revenues totalled less than RMB 100 billion. After the fiscal reform in 1980, local revenues increased rapidly, which amounted to 250 billion in 1992. In 1993, local revenues increased by 35\%, mainly as a result of tax reform in that year, not normal growth. At the beginning of the twenty-first century, central and local revenues rose over RMB 1000 billion. In 2009, the fiscal revenues were up to more than 9600 billion. $^{5}$

According to the fiscal report in 1958, the real revenues were RMB 41.89 billion, $126 \%$ of the budget (33.2 billion). It represented an annual increase of $35 \%$ (10.85 billion). Previously during the First Five Year Plan (1952-1957), average annual increase was only $12 \%$, the highest 23\% (1953). In 1958 the fiscal expenditures totalled 40.96 billion, $123.4 \%$ of the original budget ( 33.2 billion), representing an annual increase of 10.54 billion, also 35\%. Most of the extra expenditures above budget were spent on infrastructure building, which amounted to 21.4 billion, a $70 \%$ increase compared with the previous

51953-2000 data from China Statistics Yearbook 2001. 2001-2008 from China Statistics Yearbook 2009. 
year of 12.6 billion. The number did not include local governments raising fund outside budget for infrastructure building. ${ }^{6}$

Although high investment and growth rate was sustained in 1958 as the central government mobilized local initiatives to carry on autonomous industrialization, the trend abruptly turned downward when the USSR withdrew all investment and experts in 1960. The national economy slid by $21 \%$. The government managed to maintain high fiscal revenues for three more years till 1961. Afterward, the economy tumbled into recession. In fact, discounting the means of balancing by debt, fiscal revenues had been actually declining since 1957 and hit the bottom in $1960 .^{7}$

Figure 4 shows three fiscal deficit crises before the Reform. However, when the whole society bore the tremendous price of national industrialization, the weight of secondary industry in national economy surpassed $40 \%$ for the first time in history. The volume of industrial production jumped to a new level (Table 1).

In summary, since new China kicked started national industrialization, the decentralization of power during 1958-1960 was the first occasion, with the aim of mobilizing domestic local resources to substitute for disrupted foreign capital input. A relatively high level of accumulation for industrialization was thereby sustained.

In this period, mass mobilization became a relatively effective means to extract surplus from the labour force and to substitute for capital, which was in absolute scarcity. By some popularized version of "class struggle" and instrumental theory of "continuous revolution", almost the whole population (officials, intellectuals and general folk) were mobilized to contribute their labour into infrastructure building which was essential for state industrialization. The process of labor-based infrastructural building would in turn create demand for large equipment manufacturing. And both the infrastructure and manufacturing were owned by the state.

${ }^{6}$ Source: 关于 1958 年财政收支决算和 1959 年财政收支预算草案的报告 (Report on 1958 Fiscal Revenue and Expenditure Settlement Account and 1959 Fiscal Budget Draft).

${ }^{7}$ Calculation according to data in China Economic Web Statistics Data Base. 
Table 1 Major economic indicators in China 1957-1962

\begin{tabular}{|c|c|c|c|c|c|c|}
\hline Indicator & 1957 & 1958 & 1959 & 1960 & 1961 & 1962 \\
\hline $\begin{array}{l}\text { GNP (100 } \\
\text { million) }\end{array}$ & 1069.3 & 1308.2 & 1440.4 & 1457.5 & 1220.9 & 1151.2 \\
\hline $\begin{array}{l}\text { Second } \\
\text { Industry (\%) }\end{array}$ & 29.6 & 37 & 42.7 & 44.5 & 31.9 & 31.2 \\
\hline $\begin{array}{l}\text { Fiscal Revenues } \\
(100 \mathrm{~m})\end{array}$ & 303.2 & 379.62 & 487.12 & 572.29 & 356.06 & 313.55 \\
\hline Growth (\%) & 8.2 & 25.2 & 28.3 & 17.5 & -35.8 & -11.9 \\
\hline $\begin{array}{l}\text { Revenues/GNP } \\
(\%)\end{array}$ & 28.4 & 29 & 33.8 & 39.3 & 29.2 & 27.2 \\
\hline $\begin{array}{l}\text { Expenditures } \\
(100 \mathrm{~m})\end{array}$ & 295.95 & 400.36 & 543.17 & 643.68 & 356.09 & 294.88 \\
\hline $\begin{array}{l}\text { Annual } \\
\text { Increase (\%) }\end{array}$ & -0.9 & 35.3 & 35.7 & 18.5 & -44.7 & -17.2 \\
\hline $\begin{array}{l}\text { Commodity } \\
\text { Retail Price } \\
\text { Index (last } \\
\text { year }=100)\end{array}$ & 101.5 & 100.2 & 100.9 & 103.1 & 116.2 & 103.8 \\
\hline $\begin{array}{l}\text { Urban-rural } \\
\text { residents } \\
\text { RMB Saving } \\
\text { at Year End } \\
(100 \mathrm{~m})\end{array}$ & 35.2 & 55.2 & 68.3 & 66.3 & 55.4 & 41.2 \\
\hline $\begin{array}{l}\text { Financial } \\
\text { Institution } \\
\text { Cash Put into } \\
\text { Circulation } \\
(100 \mathrm{~m})\end{array}$ & -4.5 & 15.0 & 7.3 & 20.8 & 29.8 & -19.2 \\
\hline $\begin{array}{l}\text { Raw Coal } \\
\text { Production } \\
\text { (100 million } \\
\text { tons) }\end{array}$ & 1.31 & 2.7 & 3.69 & 3.97 & 2.78 & 2.2 \\
\hline $\begin{array}{l}\text { Electricity } \\
\text { Generation } \\
\text { (100 million } \\
\text { Watt-hour) }\end{array}$ & 193 & 275 & 423 & 594 & 480 & 458 \\
\hline $\begin{array}{l}\text { Pig Iron } \\
\text { (10,000 tons) }\end{array}$ & 594 & 1369 & 2191 & 2716 & 1281 & 805 \\
\hline $\begin{array}{l}\text { Crude Steel } \\
(10,000 \text { tons })\end{array}$ & 535 & 800 & 1387 & 1866 & 870 & 667 \\
\hline $\begin{array}{l}\text { Concrete } \\
\text { Cement } \\
\text { (10,000 tons) }\end{array}$ & 686 & 930 & 1227 & 1565 & 621 & 600 \\
\hline
\end{tabular}

Sources: China Statistics Yearbook 2001，新中国60年 (New China 60 Years) (China Statistics Press, 2000). Data in table are slightly different from government reports 
During the 1960s, China emphasized "self reliance". In a condition of capital scarcity, labour was the primary factor of substitution. And labour could be mobilized nationwide at a large scale as a legacy of longterm war and agrarian reform. Moreover, the communal cooperation in traditional rural community was also conductive to the formation of social capital. In the eyes of the west and its dominant ideology of individualism, this is represented as a form of totalitarianism suppressing individuality.

One aspect is noteworthy. During the "captialization of the labour force", staff democracy (as expressed by, for example, the Anshan Steel Constitution) took shape. It later went into conflict with management model when the capitalist mode of production was introduced from the West and Japan during the 1970s. The coexistence of these two essentially different models made state-owned enterprises seem inefficient and difficult to manage. Capitalist standards of measuring efficiencycapitalist rationality_-made workers appear passive and slack in work. Serious fiscal deficits eventually led to crisis during 1978-1979. (In the next chapter, we will explain how the state-owned enterprises helped to resolve the crisis of the urban youth returning to cities and led to their "inefficiency".) As a response to the crisis, concessions of power and profit from the state to enterprises gave birth to state-owned enterprise reform during the mid-1980s when monetarization and the capitalization of economy was accelerating. As the dominance of the managers over enterprises, who acted as the personification of capital, was recognized, the ownership reform during the 1990s became inevitable. When profit-optimization became the guiding principle, large-scale layoffs and dismissal prevailed, along with corruption and cronyism. We will explore this further when discussing the 1978-1979 crisis.

Back to the 1960s. Without proper conditions to set up feasible learning mechanism for industrialization, the only experiences Chinese local governments could learn from when suddenly granted the power to capitalize resources were the USSR model and national mobilization during revolutionary war. As a consequence of "path dependence", local industrialization without technology and management experience mushroomed everywhere throughout the country. Admittedly, without technological support from the USSR, local officials knew little about 
developing the steel industry. Consequently, industrialization in that period was high-cost and wasteful. Yet there is more to be gleaned from this episode than just regarding it as a "learning cost".

During that period, a young and strong labour force that was sizeable in number was mobilized to leave agriculture behind and move into industrialization ("the Great Steel Forging"). According to the memoirs of Xue Muqiao, then the Deputy Director of National Planning Committee and Director General of National Bureau of Statistics, up to 90 million of workers were involved in the steel industry. Including assistants and supporters, the number was over 100 million. A drastic cut in the labour force had a great impact on peasant agricultural production replying on intensive labouring and household mixed sideline operations (such as husbandry and handicrafts).

Even though the economic and social cost was tremendous, national industrialization was at least salvaged from total disruption and the regime just taking a footing could avert being destabilized. The completion of socialist transformation in 1956 contributed a lot to the viability of mass mobilization for the primitive accumulation of national industrialization.

State capitalist industry along the lines of the Stalinist model of introducing heavy and military industries quickly took root in China. To accommodate this system, all private sectors and peasant household economy were converted by "the socialist transformation" in 1956 . Social units composed of urban institutions and rural cooperatives were formed in the process. They later became the carrier of nation-wide mobilization. It was only with cooperatives that the government was able to fulfil a lot of tasks requiring a large extraction of surplus value from the countryside, for example, staple foods purchase, building agricultural infrastructure and pension for the families of deceased soldiers. However, the burden on cooperatives therefore became too heavy. Some peasant households would rather withdraw from the cooperatives ${ }^{8}$ (Table 2).

In 1960, China had recorded the highest fiscal revenue since 1949 with RMB 57.229 billion. However, the economic growth dropped

8叶扬兵 (Ye Yangbing) “1956-1957 年合作化高潮后的农民退社风潮” (The Tide of Peasants Withdrawing from the Cooperatives after the 1956-1957), Nanjing University Journal (Philosophy, Human Sciences and Social Sciences), 2003(6). 
Table 2 Composition of different economic sectors (Unit: \%)

\begin{tabular}{|c|c|c|c|c|c|}
\hline \multirow[t]{3}{*}{ Year } & \multicolumn{3}{|c|}{ Public economy } & \multicolumn{2}{|c|}{ Non-public } \\
\hline & \multirow[t]{2}{*}{ State-owned } & \multicolumn{2}{|l|}{ Collective } & \multirow{2}{*}{$\begin{array}{l}\text { Capitalist } \\
\text { economy }\end{array}$} & \multirow{2}{*}{$\begin{array}{l}\text { Individual } \\
\text { economy }\end{array}$} \\
\hline & & Cooperative & $\begin{array}{l}\text { Private-public } \\
\text { Joint-venture }\end{array}$ & & \\
\hline 1952 & 19.1 & 1.5 & 0.7 & 6.9 & 71.8 \\
\hline 1957 & 33.2 & 56.4 & 7.6 & 0.0 & 2.8 \\
\hline 1978 & 56.2 & 42.9 & 0.9 & & \\
\hline 1997 & 41.9 & 33.9 & 24.2 & & \\
\hline 2005 & 31.0 & 8.0 & 61.0 & & \\
\hline
\end{tabular}

Data source: National Bureau of Statistics, 伟大的十年 (The Great Ten Years). Beijing: People's Press, 1959, p. 36; “数字看变化: 国有经济地位稳固非公经济比重上 升" (State-owned Economy Steady, Non-public economy Rising) https://www.jia odong.net/news/system/2002/10/08/00532129.shtml; 李成瑞 (Li Chengrui), “关于 我国目前公私经济比重的初步测算" (Preliminary Estimation of the Ratio of Public and Private Economies) https://www.wyzxsz.com/Article/Class4/200605/6832.html. Quoted from 王绍光 (Wang Shaoguang), “坚守方向、探索道路: 中国社会主义实践 六十年" (Sixty Years of Socialist Practices in China), 中国社会科学 (China Social Science), 2009(5)

below zero with the situation described above. Furthermore, a huge fiscal deficit was also recorded due to over-investment into infrastructure by the state. Under government corporatism, the urban economy was mired in a recession as a result of the fiscal crisis. Urban employment crumbled from the peak of 130 million in 1960 to 45.37 in 1962, a deep cut of 80 million in two years.

As a response to the crisis, the government had to take a "recuperative policy" in 1961, mobilizing millions of urban citizens to countryside in order to release the unemployment pressure in the urban sector. By the expulsion of labour, state industrial capital in cities could achieve a "softlanding" in the urban economy.

During the recession in 1961-1962, government's annual fiscal revenue further dropped from 57.23 to 31.36 billion, back to the level of 1957. At the same time, China had to face the problem of food scarcity. Since 1950, the national debt to the USSR had amounted to about US\$ 5.4 billion, which were to be repaid by agricultural and pasture products, as well as precious minerals. The shortage of agricultural products within the country led to disastrous consequences. 
The estimation of China's population change during 1960-1962 has been controversial and charged with political implication. According to the revised data published by the government in 1982, the population growth curve turned downwards during these three years. Some researchers estimate that population growth for this period had failed to reach estimated projections by some 20 million. Most of this was caused by declining fertility and infant mortality because of malnutrition. And part of the rising adult mortality could be directly attributed to starvation. In official documents, the economic crisis and depression during these years was known as "three years of natural disaster".

The economic recovery in 1962-1963 was in fact not due to growth in urban industrial sector and employment. The reason was instead the concession to the peasants. Under the pressure of crisis, the government had to adjust the policy of rural collectivization. Traditional peasant economy based on village community in Rural China was once again granted with permission. Peasant households were allowed to partly withdraw from the highly collectivized economy which served the state industrial capital. First, the all commanding economy based on people's communes was converted into village economy based on production brigades, which were formed based on natural village as the basic unit of accounting and administration. This meant that traditional village-based peasant economy was allowed to partly withdraw from the state-initiated collectivized economy at county level. Second, peasant households were permitted to independently cultivate some of the reserved lands within production brigade (natural village), which meant mixed-operation rural households were allowed to partly withdraw from the collectivized economy that was strictly controlled by the state. ${ }^{9}$ In practice, the state capitalist government taking shape during the "complete sovietisation" in the 1950s relieved part of its control over the peasants. Because of it, agricultural production gradually recovered. Fiscal revenues increased thanks to continuous production growth. The weight of agricultural tax in national fiscal revenues rose from $8 \%$ in the 1950s during the first

\footnotetext{
${ }^{9}$ At that times, the lands peasant households could reserve for their disposal amounted to about $15 \%$ of total arable lands. Fifteen years later in 1977, a reform in rural economy similar to this practice was staged, known as "joint production responsibility contract system". In fact it was because the government retreated from agriculture which was no longer profitable.
} 


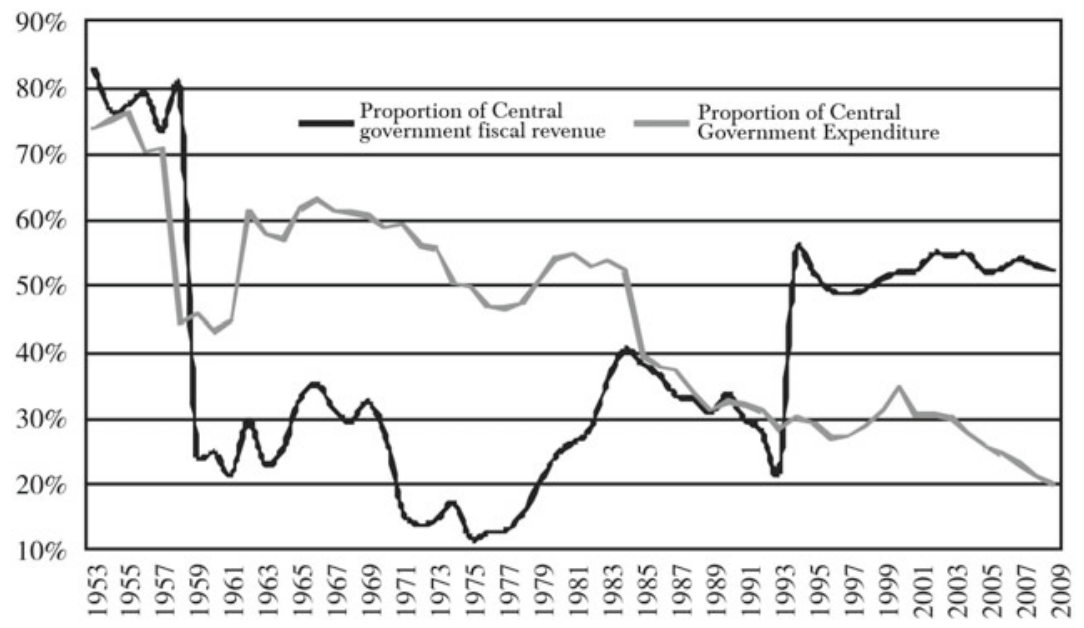

Fig. 5 The weight of central Government's fiscal revenues and expenditures 1953-2009

phase of national industrialization to $22 \%$. The fiscal condition was ameliorated. ${ }^{10}$

The variation in policy was reflected on fiscal revenues and expenditures, as well as the weight of central government's share in the total fiscal budget. After 1961, the central government resumed its centralized management on national economy, taking back the power that had been decentralized a few years before. The central government's fiscal expenditures stayed above $50 \%$ and even $60 \%$ except a few years. It was until 1984 when the central and local governments had separate fiscal budgets did the power of the central government decrease (Fig. 5).

\footnotetext{
${ }^{10}$ Wen Tiejun, “周期性经济危险及对应政策分析” (Analysis on Cyclic Economic Crises and the Measures in Response), https://www.macrochina.com.cn/zhtg/20010608007807.shtml.
} 


\section{The Third Crisis (1968-1970): Strategic Adjustment of "Three Defence Lines Construction" ${ }^{11}$ and Economic Crisis}

During the late 1960s, a period which is now regarded as the "ultraleftist age", the third crisis, also the second cyclic crisis since kick-starting the primitive accumulation for industrialization, broke out. Apart from general economic factors, it was characterized by the reaction of the super structure on the economic base.

At that time, China was under a total blockade and faced the pressure of an intense geo-political situation. At the same time, the governmental system built to accommodate the USSR model heavy-industry had been shown to be incompatible with the later "self-reliance and recalcitrant struggle" economic principle based on the mass mobilization. Both the external geo-politics and internal bureaucratism exerted reaction on the economic base shaped earlier by USSR investment. The latter had to adjust itself. In this complication, China suffered from another "deficits plus unemployment" crisis in the urban economy after repaying huge amount of foreign debt.

Before this crisis, there were debates on the guiding principle of the Third Five Year Plan and the abortion of the National Planning Committee. The Second Five Year Plan was aborted after the USSR withdrew strategic investment in 1957. In the early 1960s, chief officials responsible for economy, discussing the Third Five Year Plan, proposed to adjust the weight between agriculture, light and heavy industries, as a remedy to the Stalinist state capitalist structure which relied too much on heavy-military industry.

From the perspective of improving China's economic structure, it was definitely correct. Nevertheless, the most imminent problem then was the intensifying geo-political situation. China was up against with a series of regional "hot" confrontations: Kuomintang's attempt to strike back, China-India War and the Indochina wars. At the same time, American

\footnotetext{
${ }^{11}$ Translator's note: 三線建設 (sanxian jianshe) can also be understood as "three tiers" construction as nowadays people in China would say tier 1, tier 2, tier 3 cities, etc. Here we use "three defense lines" to emphasize its national defense background.
} 
battleships and airplanes were constantly trespassing China's territorial waters (over 800 incidents according to official records). Furthermore, both the USSR and the USA were exploring the possibility of a nuclear attack on China. During the Cold War, China was actually on the brink of hot war.

Therefore, despite various arguments on the principle of economic building during the 1960s, Mao's opinion prevailed. On the one hand, all the technological capacity had to be invested into developing nuclear weapon. As Mao said, "Even a beggar must have a stick to drive off dogs." On the other, it was felt that parts of the industrial infrastructure along the coastal regions should be relocated in the hinterland to minimize the risks of military destruction. A brink-of-war economic model took shape. The overall layout of the national industry had to be restructured into three major layers of defense lines whereas regional industries comprised respectively three layers of minor frontlines of their own.

Meanwhile, the National Planning Committee responsible for the Third Five Year Plan was replaced. The idea of transplanting a foreign institution according to the planned economy model as conceived by experts trained in and returned from the USSR became futile. Moreover, without external investment and market demand as the country under a total blockade, and the economic system being incompatible with the "self-reliance" economic line, the reform of the Soviet superstructure became imperative.

Without taking into consideration the surrounding geo-political situation, researchers applying western micro-economic theory would come up with an absolutely negative assessment on the Chinese economy during the 1960s. Furthermore, the more negative an evaluation is, the more politically correct it seems to be in terms of economic rationality. According to the cost-efficiency analysis, China's three-layer industrial layout aiming at defence consolidation was extremely costly yet without economic returns. During 1965-1975 (including the Fourth Five Year Plan), nearly half of the national infrastructure investment was put into the construction of three layers of defence lines. It is estimated that from 
1965 to the 1980 s the total funds invested into the "three defence lines" amounted to RMB 205.2 billion. $^{12}$

Admittedly, the three-layer construction was merely a spatial translocation of state industrial capital. It did not "vertically" upgrade the industrial structure. After the enterprises were transferred deep into the hinterland and mountainous regions, they became disperse geographically and hard to coordinate. The increment of the cost of industrial development in the 1960s was remarkable. It inevitably led to fiscal deficits. When crisis broke out as a result, the state once again relied on transferring the cost of the urban economy to the rural sector.

\section{Box 2: Three Defence Lines Construction Since the 1960s}

In the 1950s, Soviet economic advisors had suggested that China must concentrate on coastal regions and northeast to accelerate economic development. At the beginning, China accepted the advice. However, after giving a second thought, Chinese leaders found it risky. As the Korean War was raging on, if all the 156 projects located in the Northeast close to Korea and coastal regions were susceptible to bombing, China's industrial system especially the defence industry would be on a shaky ground. Therefore, Mao Zedong and other leaders proposed that some of the projects should be allocated in the western regions. At least half of the military defence projects should be located in west China. After consultation with the USSR, 21 of the 106 civil industrial projects and 21 of the 44 military defence projects were located in the western regions.

During the First and Second Five Years Plans, the production bases of jet planes, tanks, rockets and battle ships were located in west China. Western regions laid the industrial foundation for steel making, electricity generation, coal extraction, petroleum, nonferrous metals, weapons, aviation, construction materials and electronics, etc.

1. The International Background

12李彩华 (Li Caihua) \& 姜大云 (Jiang Dayun), “我国大 ‘三线建设” 的历史经验和教 训” (China's Three Defence Lines Construction: experiences and lessons), Northeast Normal University Journals (Philosophy and Social Science), 2005(4):89. 
In the early 1960s, China was surrounded by a very harsh international environment. The major threats were from two superpowers, the USA and the USSR which were armed with atomic weapons.

In 1964, the USSR deployed a million soldiers along the border with China and sent troop into Mongolia. Some of its strategic missiles targeted China's major cities and military facilities, and were aimed at China's atomic bomb construction site.

Meanwhile, the USA was surrounding China. Since 1960-1964, several countries in the region formed an anti-China alliance with the US. There were a few dozen US military bases in the regions. In August 1964, the USA started to bomb Northern Vietnam.

Moreover, Chiang Kai Shek in Taiwan, supported by the USA, was planning to strike back on the mainland. Spy infiltration and armed attacks were frequent in coastal regions near Taiwan. Chiang planned to create a "guerrilla corridor" in the southeast.

Mao thought that the whole heavy and military industries in northeast China was under the attack range of the USSR. Major coastal cities were also within the airstrike of Chiang's military power. Even if the enemies did not use atomic weapons, most of China's industrial infrastructure would be destroyed in case of war. Meanwhile the western hinterland was beyond the military impact of the USSR and Chiang.

Therefore, from the perspective of war preparation, the central government made two decisions. First, China had to build an atomic bomb. Second, China would launch Three Defence Lines Construction. The layout of China's industrial infrastructure would be spread out with one line in coastal regions, the second in mid-China, and the third in west and northwest China. Mao emphasized the strategic importance of Three Defence Lines Construction. The atomic bomb project was also located in the third defence line.

Since 1965, some industrial enterprises in the coastal regions were moved to west and northwest China. In that year, most of the new projects were allocated in the western regions.

In 1969, a minor military clash between the USSR and China occurred in border. To deal with the military threat from the Soviet Union, Mao further proposed "minor three defence lines". Each province had to set up their three defence lines system. The major three defence lines and other minor three defence lines would make a holistic system. 
Since 1970, "three defence lines projects" were financially prioritized by the central government.

Furthermore, these projects had to make use of special terrain and geographical features for better protection. They had to be far away from major and medium cities and disperse so that in case of nuclear war, these factories and research centres would remain intact and continue to function to support the front lines.

In a word, economic efficiency was not a major concern of these projects.

2. Financial and Managerial Support to the Three Defence Lines Construction

Three Defence Lines Construction was a systematic project requiring fiscal support and complementary industrial layout.

To complement the project, heavy industry, especially the steel industry had to be robust to provide military industry with materials.

Major military personnel and scientific talents were sent to western regions for the atomic project. During the Cultural Revolution, Mao ordered military takeover of some major "Three Defence Lines" projects, with soldiers directly working at these sites.

The projects were commanded by Party's Secretariat of the Central Committee and the State Council. Regional committees were also set up, all led by local first party secretary.

The related financial investment was enormous. During 1965-1975, nearly half of the national infrastructure fund was allocated to the projects. In 1965-1971, the total investment had amounted to RMB 34.08 billion, not including local minor projects.

According to the Fourth Five Years Plan, the defence industry cost RMB 9.123 billion in 1970-1972, about $16 \%$ of total industrial infrastructure investment, ${ }^{13}$ the highest three-year record between 1949 and 1985. By estimation, from 1964 to the mid-1980s, the total investment by the central government into the projects amounted to RMB 205.2 billion.

3. Military-heavy industry in western regions was consolidated by the Three Defence Lines Construction 
Over 1100 large and medium size industrial, transportation and defence technology enterprises, research centres and universities were built accordingly. A geographically disperse industrial system with coordinating sectors such as transportation, electricity, coal, chemical industry, petroleum, construction materials and steel making, was formed.

The decision to build six major railways in the regions was made in August 1964 by the central government. By the mid-1980s a complex railways system was functioning in these regions. In addition, complex highway systems were also constructed. Together they laid the foundation for mining, logistics, industrial and defence construction.

4. The strategic significance of Three Defence Lines Construction

Three Defence Lines system granted China a relatively safe home front. At the same time, China's military deterrence began to take shape. The projects were quite unprecedented in world economic and military history.

In 1973 when the US and China became strategically closer in the new global geopolitical situation, the system had reached a certain scale. Judging from the military and technological level at that time, China was equipped with quite an indestructible home front which could support long-term war. The problem of industrial overconcentration of industry in the coastal cities had been ameliorated.

When visiting western regions in the early 1990s, former president Jiang Zemin called for a better understanding of the significance of the Three Defence Lines Construction from the perspective of the international background.

In 1999, the central government put forth the Western Development Strategy. It was based on the historical experience of the Three Defence Lines Construction, with the view of the practical need of contemporary economic construction.

Source: Liaoning Party History Research Laboratory, “毛泽东在1964 年的一个重大决策: 建设大三线” (Mao Zedong's major decision in 1964: Three Defence Lines Construction), 决策探索 (Policy Decision Exploration) (II), 2009(2); 彭成刚 (Peng Chenggang), “斯大林模式 
在中国的历史考察” (Stalin Model in China: A Historical Survey), Wuhan Polytechnic University Master Thesis, 2006: 40-41.

In the 1960s, China's self-reliant national industrialization depended on increasing governmental investment. Moreover, the pressure of debt repayment primarily to the USSR also contributed to fiscal deficits. The situation was aggravated by the country's declining growth rate. The response to crisis was in line with what happened during 1958-1960. Millions of young unemployed urban citizens were mobilized to country sides. Apart from munitions factories and three defence lines related construction which employed limited numbers of new workers, most of the urban industrial economy in coastal regions just maintained a state of simple reproduction.

In a word, the second crisis caused by fiscal deficits achieved "softlanding" once again through transferring the cost of crisis to rural communities.

The economic inefficiency of the Three Defence Lines Construction has drawn many criticisms from scholars on the grounds of its rationale and necessity. Here, we do not want to get involved into this sort of dispute with presupposed value judgement. However, readers should be reminded of the facts used to be covered up by factional disputation. China's response to western geo-political strategy during the 1960s-70 s should not be explained by "left or right" ideologies originating from the west.

We suggest one should reflect on this problem based on the real situation relevant to China at that time. In the 1960s-1970s, China had paid an enormous cost to sustain the state capitalist industry bequeathed from the age of total sovietisation in the 1950s. Then what was being consolidated was the bureaucratic superstructure having footing on this economic base.

13 当代中国的基本建设(上)(Contemporary China's Infrastructure Construction Book 1). Beijing: China Social Science Press, 1989: 161. 


\section{$4 \quad$ The Fourth Crisis (1974-1976): The Last "Going to Mountains and Villages" Movement}

Background: Foreign Debt in the 1970s—-the Second Round of Introducing Foreign Capital at a Larger Scale to Adjust Economic Structure.

Before the twenty-first century, China was constantly under pressure of fiscal deficits. Economic crisis would lead to increasingly serious fiscal and financial deficits. The fiscal budget and finance was the core of superstructure, government being its agent. Hence, whenever there was a major policy change, the background was always a fiscal and financial problem.

In fact, all of the economic crises in modern China, including major regime changes in the twentieth century, were closely related with its opening to the world. For example, the Foreign Affairs Movement in late Qing introduced foreign facilities and raw materials, leading to fiscal, foreign exchange and currency crises. The Qing dynasty had been doomed long before it officially ended in 1911. The result of Foreign Affairs Movement was the formation of scattered regional industries controlled by local military powers. Nevertheless, the foreign factor China faced was not unchanging. It was the international environment in which China was deeply entangled whereas the institutional benefits were acquired by core countries and the costs were being transferred to the semi-periphery and periphery.

China's opening up before the twenty-first century could be attributed to the measures in response to the domestic scarcity of capital. It was a process of improving the conditions for foreign capital as a quid pro quo for the benefits of national industrialization. Entering into the twenty-first century, it became an active strategic choice of domestic industrial capital facing the problems of excess capacity and insufficient domestic demand, while the gaps between the rural and urban, the poor and the rich, as well as the developed and less-developed regions have been widening. Opening was now a channel to release overcapacity into international market. Domestic excess industrial capacity seeks new opportunities in international market while internal capital 
coming under the pressure of a mounting financial bubble is seeking cheap factors of production in China.

\section{New Geopolitical Condition in the 1970s}

In the 1970s, the international and geopolitical condition in which China was situated changed once again. As technology was developing in the 1960s, the first post-war global industrial structural adjustment took place. It was dominated by the advanced countries where labour cost rose up and capital-labour confrontation intensified. Labour-intensive industries were transferred to developing countries while the advanced countries devoted themselves to upgrading their economic structure to capital and technology-intensive industries. Those countries and regions without institutional barrier accepted this first round of industry transfers. Korea, Taiwan, Singapore and Hong Kong belonged to the Confucian cultural circle without major institutional barriers and therefore received industry transfer from Japan. They adopted an export-oriented strategy aiming at labour-intensive manufacturing. These economies experienced economic booms in a short period of time and were called the Four Little Dragons of Asia.

Nevertheless, the Four Little Dragons were geographically small. Industry transfer rapidly re-priced the production factors of the recipients. In order to secure profitability, capital seeking after short-term returns had to move into countries or regions where land, resources and labour were even lower in price.

1972 was a year pivotal for both China and the world. After the disintegration of the Bretton Woods system, global capitalist system moved onto a new stage. The supply of US dollar as a global currency was sky-rocketing. The economic structure of advanced countries became hyper-modernized and increasingly financialized, with industrial capital flowing out seeking after cheap labour, land and resources. The astronomical expansion of US money supply catalyzed financial innovation drawing open the curtains of the age of financial globalization, in which unfettered speculation of derivatives was encouraged so as to absorb excessive liquidity as the supply of dollar was no longer limited. 
Meanwhile, lifting two decades of economic blockade, the USA was reconciled with China which took the chance to. Mao accepted the judgement of his generals and military advisors that a world war would not take place in the next 20 years. Under the military pressure from the USSR along the borders, he directed the rapprochement with the West. China took advantage of the acute confrontation between the two superpowers to turn to the West including Japan to reform its economic structure. However, it also had to make concessions to the West by adjusting its geo-political relationship with peripheral countries. For example, China promised to give up supporting communist movements in the regions. This once again afforded China with the chance to take part in the international division of labour and exchange. By introducing industrial facilities, technology and management models from the US, Europe and Japan, China started to adjust its economic structure which comprised too high a ratio of heavy industry and endeavored to establish a balanced industrial system with diversified sectors.

The principle of economic structural adjustment of the second introduction of foreign facilities, technology and management model since 1972 was actually congruent with the general thought of the Third Five Year Plan, which in 1963 had to be aborted so as to construct the three-layer industrial layout.

Gripping the chance, Premier Zhou Enlai proposed the "43 Plan", introducing US\$ 4.3 billion of industrial facilities from western countries. China's second round of relatively autonomous opening was thus initiated. The projects were generally concentrated in coastal major industrial cities.

However, the cost of introducing even more expensive western technologies in the 1970s was obvious. Before long, economic crisis once again broke out.

Since the late 1960s and early 1970s, China made use of foreign exchange reserve as well as deferred payment to import US\$ 4.24 billion of machinery. ${ }^{14}$ Then instantly, China faced the problem similar to the

14 石林 (Shi Lin), 当代中国的对外经济合作 (Contemporary China's Economic Cooperation). China Academy of Social Science Press, 1989: 320. Quoted in 崔新健 (Cui Xinjing), 中国 利用外资三十年 (China Making Use of Foreign Capital in 30 Years). China Financial and Economic Press, 2008: 6. 
time after the First Five Year Plan was completed, when it "opened up" to the USSR: the state's lack of capability to sustain investment to enlarge reproduction. After 1974, fiscal deficits broke through RMB 10 billion whereas the total fiscal budget at that time was less than 80 billion.

Confronted with a serious fiscal crisis, the state, by path dependence, once again mobilized urban surplus labour to villages. Such was the third and last "Going to Mountains and Villages Movement". During 1974-1976, millions of capable labours not being absorbed by the urban economy were sent to rural collectives, as the direct cost-transfer of crisis from cities to the sannong. However, since the Cultural Revolution had ended and urban youngsters were no longer so enthusiastic to be mobilized, they were reluctant to leave cities. Furthermore, high level of investment had created some new employment opportunities in cities after 1972. As a result, the third movement did not run as smoothly as on previous occasions. Social discontent was mounting.

Then Mao Zedong, Zhou Enlai and Zhu De, the old generation of leaders who embodied revolutionary authority, passed away one after one. The appointed new leadership was more ambitious but less experienced. With rising fiscal deficits, the Hua Guofeng administration conceived an even bigger plan of introducing facilities and technologies. In 1978 alone, China signed contracts of 22 big projects up to US\$ 7.8 billion in value and other letters of intent involving another US\$ 5 billion with foreign parties. Meanwhile the fiscal revenue in 1978 was merely about RMB 113.2 billion. This round of economic adjustment by Mao's successor led to a fiscal deficit stock of more than RMB 30 billion in 1979-1980.

Consequently a typical stagflation crisis broke out. Counter-crisis measures later known as "reform" were put forth.

The "43 Plan" of Mao and Zhou in the 1970s and Hua's " 82 Plan" differed only in amount. The contents were consistent. After the USA lifted the blockade in early 1970s, China had introduced large scale industrial facilities from the West and Japan. Therefore we would group them together as the "second foreign investment" in a continuous economic process. The second foreign investment differed from the previous in one aspect: the condition of the first investment in the $1950 \mathrm{~s}$ was a strategic partnership. A number of Russian experts were sent from 
the USSR to help China. Therefore China could save a lot of technological and management cost. However, turning to the West and Japan since mid-1970s, China now had to pay expensive service cost (later known as the tertiary industry).

Similar to the first foreign investment from the USSR building China's national industrialization, this second occasion involved government corporatist behaviour at the central administration level. Furthermore, the state industry shaped by introducing the assembly line system from the USSR could not be effectively managed without the formation of a soviet superstructure. We may suggest the political unrest in the 1960s was the result of a painful attempt and failure to reshape the path dependence of the Soviet institution after the interruption of Russian aid. Likewise, the reform pushed by the central government since the late 1970s has been the reconstruction of superstructure corresponding to the economic base of the urban economy according to the western capitalist model. Now the government officials were obliged to painstakingly transform their mind and practices. They had to abandon the old mentality along with the whole obsolete institutions transplanted from the USSR. Otherwise, they would be incompatible with the new institutional requirements necessitated by the western model of production and management. Reforms in economic and political systems were gradually proposed by these officials in charge of the economy. In a sense, it is a passive form of institutional evolution.

Ironically, these two occasions of introducing strategic foreign investment were later criticized by the CPC's second generation leadership in the early 1980s after the power transition. The first was denigrated as "ultra-leftist" impetuosity whereas the second a "foreign leap forward," echoing the Great Leap Forward in the early 1960s. Nonetheless, the administrations after the 1980s followed the path dependence sustaining government corporatism and directly introduced foreign capital.

Admittedly people of that generation could not understand their situation as we can. But surprisingly, many researchers nowadays are not totally free from similar ideological judgment. Only by contextualizing these historical events into their real material conditions can we better understand the choices and actions of the social actors at a particular historical moment instead of putting simple ideological labels on them. 
We wish the readers may grasp the historical continuity of this long process and, accordingly, have a better reflection on the Western-centric discourse in explaining China's Reform.

In conclusion, the state in Mao's age took advantage of the incomplete rural land ownership and intervened in heavy-handed fashion to organize the collectivized economy in the rural sector. It did not consider the development of agricultural productivity level or take care of the interests of the peasants. Nonetheless, it did play an unexpected function in the primitive accumulation for national industrialization. Collective and even distribution could not lead to a proper incentive mechanism. However, it was characterised by a traditional practice within small rural communities, namely resolving the risk of externality by internalizing it in the community. This may be called the peasant socialism with Chinese characteristics. Thanks to it, 40 million young unemployed urban citizens were accommodated into rural communities. ${ }^{15}$ In 20 years, the sannong had, at least on three occasions, silently bore the cost of cyclic urban economic crisis caused by state capitalism.

After Mao's death in 1976, none of his successors had similar authority and charisma to mobilize unemployed urban citizens to villages in the event of urban economic crises. Afterward, most of the crises had to take "hard-landing" in cities, except the two occasions of 1979-1980 and 2008-2009.

\footnotetext{
${ }^{15}$ At personal level, many of these young urban citizens in retrospect may consider it a traumatized experience as they were being deprived of urban welfare and a normal youth. However, few of them would be grateful to the peasants who generously accepted the obligation to feed 40 millions without feeling being traumatized.
} 
Open Access This chapter is licensed under the terms of the Creative Commons Attribution-NonCommercial-NoDerivatives 4.0 International License (http://creativecommons.org/licenses/by-nc-nd/4.0/), which permits any noncommercial use, sharing, distribution and reproduction in any medium or format, as long as you give appropriate credit to the original author(s) and the source, provide a link to the Creative Commons license and indicate if you modified the licensed material. You do not have permission under this license to share adapted material derived from this chapter or parts of it.

The images or other third party material in this chapter are included in the chapter's Creative Commons license, unless indicated otherwise in a credit line to the material. If material is not included in the chapter's Creative Commons license and your intended use is not permitted by statutory regulation or exceeds the permitted use, you will need to obtain permission directly from the copyright holder. 